\title{
Interpretasi Data Geolistrik untuk Memetakan Potensi Air Tanah dalam Menunjang Pengembangan Data Hidrogeologi di Kabupaten Jombang, Jawa Timur
}

\author{
Serli Birlina $\mathrm{H}^{*}$ Darsono, dan Budi Legowo \\ Jurusan Fisika, Fakultas MIPA, Universitas Sebelas Maret \\ Ir. Sutami No.36 A Surakarta 57126
}

\begin{abstract}
Intisari
Telah dilakukan pemetaan potensi air tanah dalam menunjang pengembangan data hidrogeologi di kabupaten Jombang, Jawa Timur dengan menggunakan metode geolistrik resistivitas sounding. Akuisisi data resistivitas menggunakan konfigurasi elektroda Schulmberger. Pengolahan data dan interpretasi data menggunakan software Progress Version 3 dan pemetaannya menggunakan software Surfer. Hasil pengolahan bahwa lapisan batuan keempat kecamatan tersebut tersusun lempung dengan nilai resistivitas 6 - $10 \Omega \mathrm{m}$, lempung pasiran 11 $19 \Omega \mathrm{m}$, pasir dan pasir lempungan 20 - $90 \Omega \mathrm{m}$, serta pasir kerakalan 90 - $130 \Omega \mathrm{m}$. Akuifer (lapisan pembawa air) diduga berada pada lapisan penyusun pasir dan pasir lempungan. Hasil pemetaan menunjukkan daerah yang mempunyai sumber potensi air tanah besar terdapat kecamatan Mojowarno. Daerah yang berpotensi sumber air tanah sedang di kecamatan Bareng dan Mojowarno.
\end{abstract}

\begin{abstract}
Have done mapping of groundwater potential in supporting the development of data hydrogeology in Jombang, East Java using geoelectric resistivity soundings. Resistivity data acquisition using Schulmberger electrode configuration. Data processing and interpretation of data using Progress Version 3 software and mapping using Surfer software. The results of processing the four districts that rock layers are composed of clay with a value of resistivity 6-10 $\Omega \mathrm{m}$, sandy loam 11-19 $\Omega \mathrm{m}$, sand and sand lempungan 20-90 $\Omega \mathrm{m}$, and sand kerakalan 90-130 $\Omega \mathrm{m}$. Aquifer is believed to be the constituent layers of sand and sand lempungan. The result shows mapping shows areas that have a large potential source of ground water contained in the district Mojowarno. Potential areas of medium groundwater resources in the district Bareng and Mojowarno.
\end{abstract}

KATA KUNCI: geoelectric, sounding, Schlumberger, resistivity

\section{PENDAHULUAN}

Pemanfaatan air kian hari semakin meningkat seiring dengan meningkatnya laju pertumbuhan penduduk. Salah satu daerah yang padat penduduknya adalah kabupaten Jombang. Jaringan air bersih di kota Jombang dipergunakan untuk memenuhi kebutuhan masyarakat untuk air minum dan kebutuhan rumah tangga lainnya. Untuk air minum di Kota Jombang dilayani oleh PDAM. Sekitar 23.486 rumah tangga yang ada di kota Jombang mencakup 20 desa dan kelurahan yang terlayani air bersih dari PDAM adalah 11.426 rumah tangga atau sekitar $50 \%$ saja. Sedangkan di luar pusat kota memanfaatkan sumur pompa dan sumur gali [1].

Penggunaan sumber air tanah bersih di kota Jombang adalah 11.734.900 liter/hari, dengan jumlah penduduk 117.439 jiwa. Sedangkan yang bisa dilayani oleh PDAM kota Jombang baru 8.812.800 liter/hari. Jadi, kebutuhan air bersih yang masih harus dilayani oleh PDAM sebe-

*E-MAIL: serly_asshalihah@yahoo.com sar 2.931.100 liter/hari [1]. Peningkatan penggunaan air terkadang tidak disertai pengelolaan sumber air yang baru disebabkan kurangnya informasi mengenai potensi sumber air tanah. Potensi sumber air tanah berbeda-beda sesuai dengan kondisi geologi sekitarnya. Mengingat faktor kondisi geologi juga berpengaruh terhadap potensi sumber air tanah, maka perlu dilakukan kajian mengenai potensi sumber air tanah di kabupaten Jombang.

Berdasarkan data hidrogeologi daerah tersebut secara umum menjelaskan tentang potensi akuifer yang tersebar secara luas. Masih kurangnya informasi sumber air tanah mengenai kedalaman air tanah. Selain itu juga tidak diketahuinya pola penyebaran akuifer yang mengarah ke arah mana. Informasi yang ada tentang kondisi air tanah terbatas dan hanya dengan debit $<20$ liter/detik [2]. Terkait hal tersebut ada empat kecamatan yang kurang memiliki cukup informasi tentang potensi sumber air tanah yaitu kecamatan Mojowarno, Mojoagung, Bareng, dan Wonosalam. Air tanah yang terdapat pada lapisan akuifer, yaitu lapisan pembawa air yang berada di bawah permukaan tanah. Lapisan ini terletak pada kedalaman tertentu, bahkan bisa mencapai kedalam hingga 100 meter. Lapisan ini tersusun oleh batuan yang kedap air. Selain 


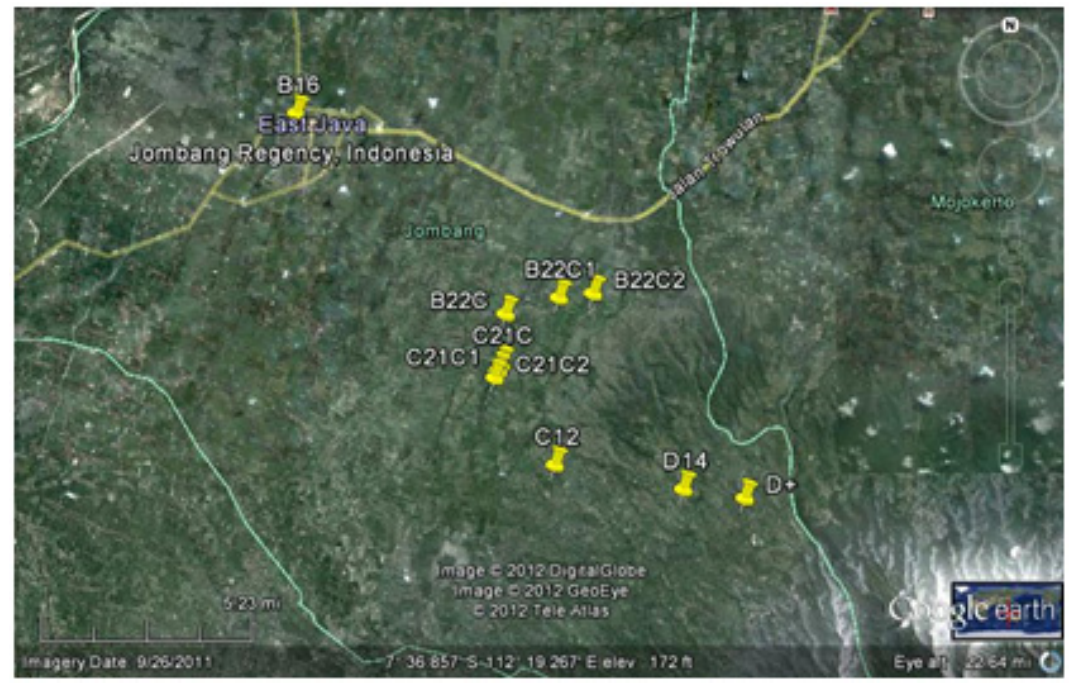

Gambar 1: Titik lokasi pengambilan data

itu lapisan ini juga memiliki porositas tertentu yang dapat menyimpan air dan mengalirkan air dalam jumlah yang cukup.

Salah satu metode geofisika yang dapat mendeteksi adanya lapisan bawah permukaan adalah metode geolistrik resistivitas. Prinsip dari metode ini adalah memanfaatkan adanya kontras resistivitas batuan terhadap tanah di sekitarnya. Hal ini dimungkinkan karena lapisan tanah dan batuan yang terisi air sangat mudah mengalirkan arus listrik atau bersifat konduktif. Lapisan tanah konduktif seperti ini biasanya memiliki harga resistivitas tertentu (resistivitasnya rendah). Hasilnya menampilkan penampang vertikal resistivitas bawah permukaan yang diprediksi sebagai lapisan-lapisan tanah atau batuan yang tersaturasi air. Sehingga dapat memprediksi lokasi dan kedalaman tempat lapisan tanah yang mengandung air tawar [3]. Metode ini lebih banyak digunakan karena tekniknya sederhana dan resistivitas batuannya sangat sensitif terhadap kadar airnya. Menggunakan metode ini kedalaman, ketebalan tiap lapisan, dan hasil kapasitas air tanah dengan mudah dapat disimpulkan [4]. Selain itu metode ini mampu menentukan perbedaan yang signifikan di dalam parameter geolistrik dari top soil (tanah penutup) dengan material lain, daerah yang retak atau patahan, dan batuan bawah tanah [5]. Metode ini juga dapat menaksirkan ketebalan permukaan tanah dengan baik serta daerah patahan dengan teliti [6].

Penelitian ini dilakukan untuk menunjang pengembangan data hidrogeologi dan pengembangan potensi air tanah. Metode resistivitas sounding untuk mengetahui perbedaan resistivitas arah vertikal yang berupa kedalaman. Dari hasil ini maka dapat dipetakan sehingga diketahui penyebaran lapisan akuifernya. Hasil penelitian inilah yang akan menunjang pengembangan data hidrogeologi kabupaten Jombang, khususnya di kecamatan Mojowarno, Mojoagung, Bareng, dan Wonosalam.

\section{METODE PENELITIAN}

Prinsip dari survei geolistrik resistivitas adalah mengukur atau menghitung nilai tahanan jenis semu material yang ada di bawah permukaan. Arus listrik searah diinjeksikan ke dalam bumi, sehingga timbul beda potensial listrik terukur. Nilai beda potensial dan arus inilah akan diperoleh nilai resistivitas semu. Namun, nilai resistivitas semu tergantung dari konfigurasi elektroda yang dipakai. Dalam penelitian ini, konfigurasi elektroda yang dipakai adalah konfigurasi elektroda Schlumberger. Pengukuran dilakukan secara sounding, sehingga hasil yang didapatkan berupa kedalaman, ketebalan, dan nilai resistivitasnya.

Arus yang diinjeksikan ke dalam bumi menggunakan dua elektroda (A dan B) dengan jarak L dari elektroda A sampai ke titik pusat $O$. Sedangkan beda potensial sebagai akibat dari penginjeksian arus terukur dengan elektroda $\mathrm{M}$ dan $\mathrm{N}$, dengan jarak $\ell$ dari elektroda $\mathrm{N}$ ke titik pusat $\mathrm{O}$. Berdasarkan pola konfigurasi tersebut, maka diperoleh persamaan untuk menghitung resistivitas semu,

$$
\rho_{a}=\frac{\pi\left(L^{2}-\ell^{2}\right)}{2 \ell} \frac{\Delta V}{I}
$$

Secara geografis, kabupaten Jombang berada diantara $112^{\circ} 20^{\prime} 01^{\prime \prime}$ dan $112^{\circ} 300^{\prime} 01^{\prime \prime B T}$ serta antara $07^{\circ} 20^{\prime} 01^{\prime \prime}$ dan $07^{\circ} 45^{\prime} 01^{\prime \prime}$ LS. Daerah penelitian berada di kecamatan Mojowarno, Mojoagung, Bareng, dan Wonosalam. Pengambilan data dilakukan sebanyak 10 titik sounding, dengan titik lokasi pengambilan data ditunjukkan Gambar 1.

Alat yang digunakan dalam penelitian ini adalah resistivitimeter merk Oyo model 2119C digital McOHM-EL, dengan elektroda sebanyak empat buah. Empat buah kabel gulung yang masing-masing panjangnya 400 meter. Meteran empat buah yang masing-masing panjangnya 200 meter. Sumber arus yang dipakai adalah arus searah yaitu satu buah accu 12 V. Untuk menentukan posisi titik yang akan diukur menggu- 


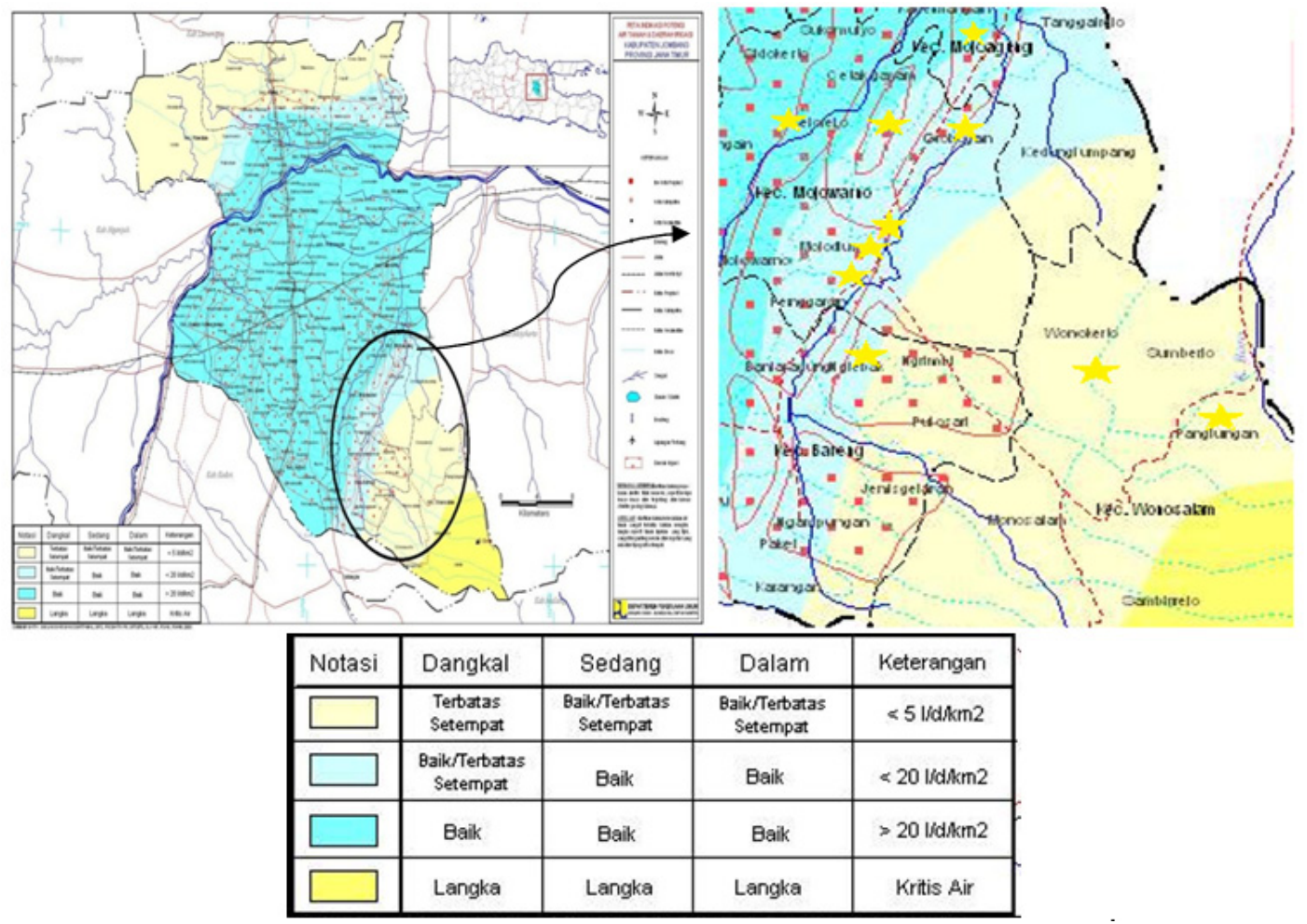

Gambar 2: Peta indikasi potensi air tanah daerah penelitian (untuk interprestasi warna, pembaca dapat melihat artikel ini versi web)

nakan GPS (Global Positioning System). Palu lima buah digunakan untuk memukul elektroda ke dalam tanah. HT (Hand Talky) empat buah untuk berkomunikasi. Peralatan tambahan yang lain yaitu multimeter, kalkulator, lembar tabel data, kertas bilog, dan alat tulis. Data yang diperoleh di lapangan berupa data resistivitas semu, yaitu resistivitas hasil pengukuran yang kemudian langsung diplotkan pada kertas bilog sebagai kontrol data pada waktu pengukuran langsung di lapangan. Kemudian diolah menggunakan software Progress Version 3.0, nilai resistivitas titik tiap soundingnya dipetakan dengan software Surfer.

\section{HASIL DAN PEMBAHASAN}

Hasil dari pengolahan data menggunakan software Progress berupa kurva resistivitas dan resistivity log, yaitu nilai resistivitas tiap lapisan, ketebalan lapisan, dan kedalamannya. Dari hasil pengolahan dapat diketahui kedalaman dan ketebalan lapisan batuan hingga kedalaman 180-220 m. Secara umum peta hidrogeologi daerah penelitian hanya mencantumkan warna yang mengidentifikasikan bahwa daerah tersebut memiliki potensi air tanah yang baik maupun kurang baik (Gambar 2), sedangkan informasi mengenai kedalaman potensi air tanah khususnya pada daerah penelitian sangat kurang.

Pemetaan dilakukan berdasarkan kedalaman, mulai dari kedalaman 0 - 30 m, 30 - 60 m, $60-90$ m, dan 90 m ke atas. Kemudian dipetakan berdasarkan nilai resistivitas meng-

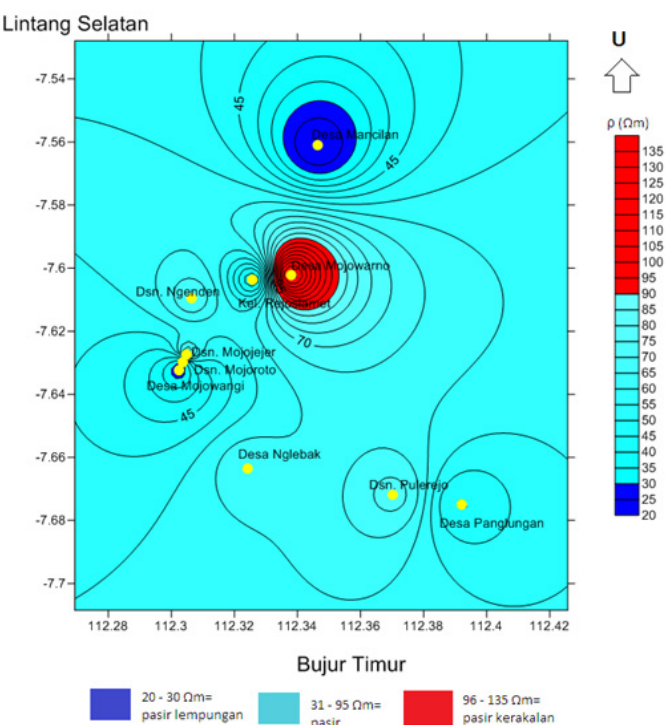

Gambar 3: Peta kedalaman 0 - 30 meter

gunakan software Surfer, untuk masukan X Bujur Timur dan Y Lintang Selatan.

Peta kedalaman 0 - 30 m (Gambar 3) menunjukkan distribusi lapisan batuan untuk masing-masing titik yang ditandai dengan warna kuning (untuk interprestasi warna, pembaca dapat melihat artikel ini versi web) sebagai titik pengambilan data. Desa Mancilan didominasi warna biru tua merupakan interpretasi lapisan batuan yang mempunyai rentang nilai re- 
sistivitas 20 - $30 \Omega \mathrm{m}$. Nilai resistivitas ini dikorelasikan dengan data sumur bor dan tabel resistivitas material [7], sehingga diperoleh dugaan lapisan jenis batuannya. Lapisan batuan ini diduga pasir lempungan dengan ketebalan lapisan sekitar $30,89 \mathrm{~m}$. Informasi peta geologi menunjukkan desa Mancilan didominasi oleh aluvium yaitu kerakal, kerikil, pasir, lempung, dan lumpur. Desa Mojowarno didominasi warna merah merupakan interpretasi lapisan batuan yang mempunyai rentang nilai resistivitas 91 - $135 \Omega \mathrm{m}$. Lapisan batuan tersebut diduga pasir kerakalan dengan ketebalan lapisan seki$\operatorname{tar} 21,45 \mathrm{~m}$. Menurut informasi peta geologi, desa Mojowarno didominasi oleh batuan gunung api anjasmara tua yaitu breksi gunung api, lava, tuff, dan retas. Sedangkan titik daerah yang berwarna biru sebagian besar didominasi lapisan batuan dengan rentang nilai 31 - $90 \Omega \mathrm{m}$. Lapisan batuan ini diduga pasir dengan ketebalan tiap titik yang berbeda-beda. Ketiga lapisan ini mempunyai potensi sebagai penyusun lapisan pembawa air atau akuifer. Batuan pasir berpotensi baik sebagai penyusun akuifer daripada batuan pasir lempungan karena batuan pasir ukuran partikel 0,02 - 0,2 mm dengan porositas $30-40 \%$ dan koefisien permeabilitas $0,1-0,01$ [8]. Batuan pasir lempungan merupakan bataun pasir yang terdapat sisipan lempung didalamnya. Batuan pasir kerakalan memiliki potensi yang lebih baik sebagai penyusun akuifer karena ukuran butir efektifnya adalah $>2 \mathrm{~mm}$ [8]. Ukuran butir tersebut lebih besar daripada pasir maupun pasir lempungan, sehingga lebih mudah dalam meloloskan air. Namun, dilihat dari ketebalan lapisan pembawa air juga berpengaruh terhadap baik tidaknya potensi akuifer tersebut. Ketebalan lapisan pasir lempungan di dusun Mojoroto dan desa Mojowangi adalah 16,39 m serta $14,84 \mathrm{~m}$. Ketebalan lapisan pasir di Kelurahan Rejoslamet adalah 76,72 m, dusun Ngenden 21,83 m, Desa Nglebak 14,24 m, dusun Mojojejer 11,34 m, dusun Pulerejo 28,96 m, dan Desa Panglungan 9,03 m. Menurut ketebalan lapisannya, desa Mancilan dan dusun Pulerejo mempunyai potensi akuifer yang baik. Namun, kelurahan Rejoslamet mempunyai potensi akuifer yang sangat baik dan lebih besar, karena mempunyai ketebalan yang lebih tebal dari kedua desa tersebut. Desa Panglungan mempunyai potensi akuifer yang kecil jika dilihat dari ketebalan lapisannya, sedangkan desa dan dusun yang lain mempunyai potensi akuifer sedang.

Peta 30 - 60 m (Gambar 4) menunjukkan distribusi lapisan batuan. Pada kedalaman 30 - $60 \mathrm{~m}$ ada daerah yang didominasi warna coklat berada di desa Mancilan merupakan interpretasi dari lapisan batuan dengan nilai resistivitas $5-10$ $\Omega \mathrm{m}$. Lapisan batuan ini diduga adalah lempung dengan ketebalan 32,65 m, di dusun Mojojejer lapisan batuannya diduga adalah lempung karena memiliki nilai resistivitas 7,49 $\Omega \mathrm{m}$. Tebal lapisan batuan lempung ini adalah 32,65 m. Namun, pada peta tidak kelihatan distribusinya, dikarenakan jarak dengan titik yang lain sangat dekat sehingga nilai tersebut tidak terdistribusikan dengan baik. Kelurahan Rejoslamet masih pada lapisan yang sama dengan atasnya yaitu pasir, karena ketebalannya $76,72 \mathrm{~m}$. Daerah yang berwarna merah yaitu dusun Pulerejo memiliki rentang nilai resistivitas 91 - 125 $\Omega \mathrm{m}$, litologi penyusunnya adalah pasir kerakalan dengan ketebalan lapisan 33,26 m. Dusun Ngenden dan desa Nglebak memiliki nilai resistivitas $21-30 \Omega \mathrm{m}$, lapisan ini diduga

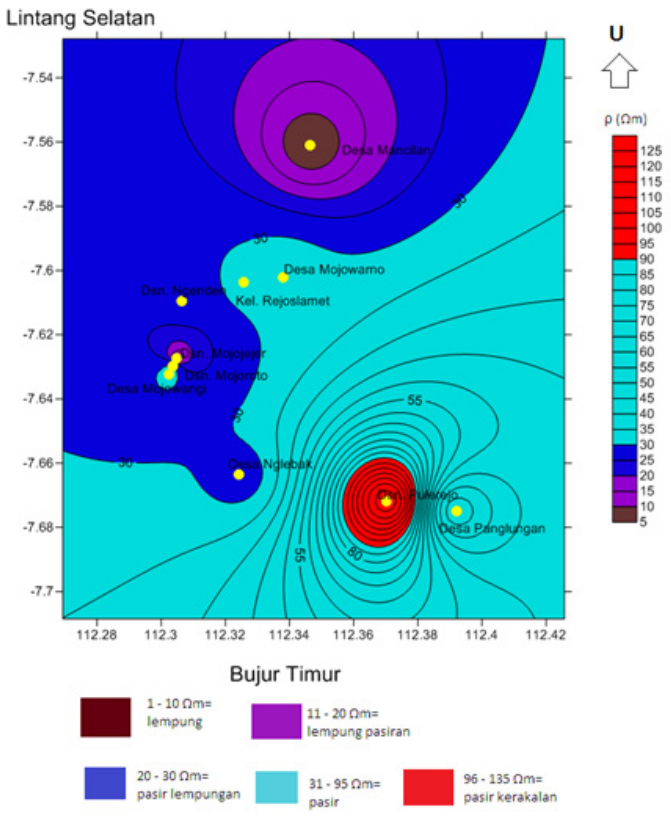

Gambar 4: Peta kedalaman 30 - 60 meter

lapisan batuan pasir lempungan. Masing-masing lapisan ini mempunyai ketebalan sebesar 24,02 m dan 20,64 m. Daerah yang didominasi warna biru muda memiliki rentang nilai resistivitas sekitar 31 - $90 \Omega \mathrm{m}$, lapisan ini diduga adalah pasir dengan kedalaman tiap titik yang berbeda-beda. Ketebalan lapisan batuan pasir di desa Mojowarno 17,64 m, dusun Mojoroto 11,22 m, desa Mojowangi 16,64 m, dan desa Panglungan 19,26 m. Kelurahan Rejoslamet masih mempunyai sumber potensi akuifer yang besar setelah itu dusun Pulerejo dan dusun Ngenden. Sedangkan desa Mojowarno, desa Nglebak, dusun Mojoroto, desa Mojowangi, dan desa Panglungan mempunyai sumber potensi akuifer sedang berdasarkan ketebalan lapisannya. Namun, desa Mancilan dan dusun Mojojejer bukan merupakan lapisan penyusun akuifer karena batuan lempung mempunyai porositas $45-50 \%$, tetapi permeabilitas yang rendah yaitu $0,0001-0,000$ [8] maka sangat sulit untuk meloloskan air. Lapisan batuan lempung ini disebut juga lapisan kedap air karena sifat dari lempung tersebut.

Pada peta kedalaman 60 - 90 m (Gambar 5) menunjukkan dusun Mojoroto dan desa Mojowangi memiliki nilai resistivitas batuan $5-10 \Omega \mathrm{m}$, diduga lapisan ini adalah lempung. Masing-masing mempunyai ketebalan sebesar $85,29 \mathrm{~m}$ dan 72,7 m, lapisan ini merupakan lapisan kedap air. Sedangkan dusun Mojojejer memiliki rentang resistivitas 10 - $20 \Omega \mathrm{m}$, diduga lapisan ini adalah lapisan lempung pasiran. Ketebalan lapisan ini sekitar 46,93 m, lapisan ini kurang baik sebagai lapisan penyusun akuifer, karena lapisan ini merupakan lapisan lempung yang tersisipi oleh pasir. Desa Mancilan dan desa Mojowarno memiliki rentang resistivitas 21 - $30 \Omega \mathrm{m}$, diduga lapisan ini merupakan lapisan pasir lempungan. Ketebalan masing-masing lapisan adalah 5,62 m dan 53,92 m. Desa Nglebak, dusun Ngenden, dan desa Panglungan memiliki rentang resitivitas sama dengan kelu- 


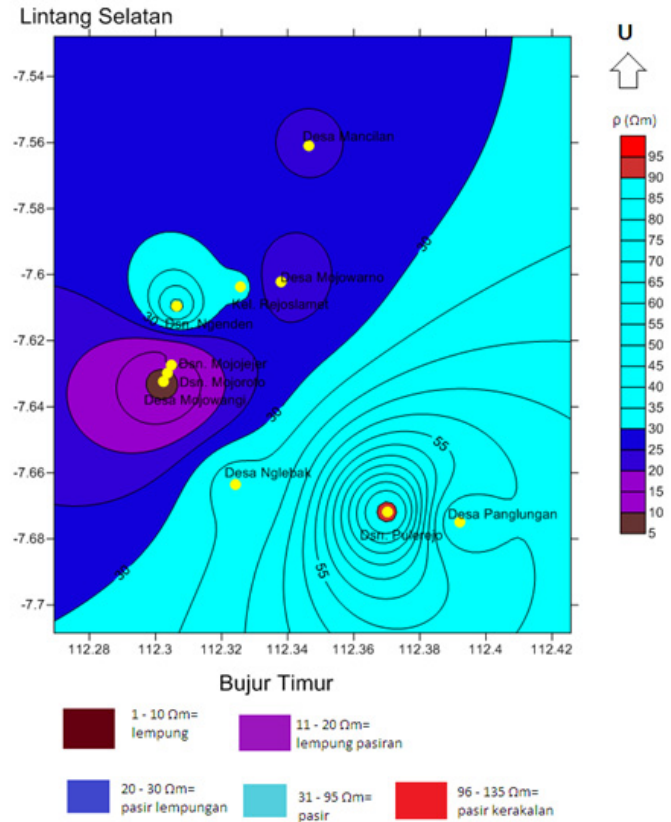

Gambar 5: Peta kedalaman 60 - 90 meter

rahan Rejoslamet diduga lapisan penyusunnya adalah pasir. Kedalaman masing-masing adalah 59,09 m, 55,83 m, dan $57,71 \mathrm{~m}$, dengan ketebalan sebesar ini ketiga desa tersebut memiliki sumber potensi akuifer yang besar kedua setelah kelurahan Rejoslamet. Dusun Mojojejer, dusun Mojoroto, dan desa Mojowangi merupakan daerah dengan potensi sumber kecil karena lapisan penyusun pada kedalaman ini adalah lempung. Pendugaan bahwa pada daerah ini tidak terdapatnya potensi air tanah bisa terjadi, karena sifat dari lempung yang sulit untuk meloloskan air.

\section{SIMPULAN}

1. Lapisan batuannya tersusun oleh lempung dengan nilai resistivitas 6 - $10 \Omega \mathrm{m}$, lempung pasiran $11-19 \Omega \mathrm{m}$, pasir dan pasir lempungan 20 - $90 \Omega \mathrm{m}$, serta pasir kerakalan 90 - $130 \Omega \mathrm{m}$. Diduga lapisan akuifer berada pada lapisan penyusun pasir karena batuan jenis pasir memiliki ukuran partikel 0,02 - 0,2 mm dengan porositas $30-40 \%$ dan koefisien permeabilitas 0,1 - 0,01. Ketebalan lapisan ini diduga antara 30 - 80 m. Lapisan penyusun lempung mempunyai porositas $45-50 \%$, tetapi koefisien permeabilitasnya 0,0001 - 0,0001, sehingga lapisan ini sangat sulit untuk dilewati air. lapisan ini bisa disebut lapisan kedap air diperkirakan ketebalan lapisan ini antara 5 - $33 \mathrm{~m}$.

2. Daerah yang mempunyai sumber potensi air tanah besar pada kedalaman 0 - 30 m yaitu kelurahan Rejoslamet ketebalan lapisan akuifer 76,72 m, dusun Pulerejo ketebalan 28,96 m, desa Mancilan ketebalan 30,89 m. Sedangkan daerah yang berpotensi kecil yaitu desa Panglungan dengan ketebalan 9,03 m. Pada kedalaman 60 - $90 \mathrm{~m}$ yang mempunyai sumber potensi besar yaitu: Kelurahan Rejoslamet ketebalan 76,72 m dan dusun Pulerejo ketebalan33,26 m. Desa Mancilan dan dusun Mojojejer terusun oleh lempung dengan ketebalan $32,65 \mathrm{~m}$ dan $32,95 \mathrm{~m}$. Daerah yang berpotensi sumber air tanah besar pada kedalaman 60 - 90 m yaitu kelurahan Rejoslamet ketebalan lapisan 76,72 m, dusun Ngenden dengan ketebalan lapisan 55,83 m, dusun Pulerejo ketebalan lapisan 46,92 m, desa Nglebak ketebalan lapisan 59,09 m, dan desa Panglungan ketebalan lapisan $57,71 \mathrm{~m}$.
[1] http://www.Jombangkab.go.id/ (tanggal akses 24 Februari 2012)

[2] -, Peta Indikasi Potensi Air Tanah Kabupaten Jombang, Departemen Pekerjaan Umum (tanggal akses 22 Mei 2012)

[3] Sultan, Jurnal Penelitian Enjiniring (ISSN: 141-6243), 12 (2), 151-158 (2009).

[4] S. Selvam, P. Sivasubramanian, International Journal of Geomatic and Geosciences (ISSN:0976-4380), 3 (1), 55-62, (2012).

[5] G.K. Anudu, L.N. Onuba, L.S. Ufondu, Journal of Applied Technology in Environmental Sanitation (ISSN:2088-3218), 1 (4),
343-354, (2011)

[6] J.O. Coker, International Archive of Applied Sciences and Technology (ISSN:0976-4828), 2 (2), 27-33, (2012).

[7] W.M. Telford, L.P. Geldart, R.E. Sheriff, Applied Geophysics (Second Edition. Cambridge University Press, 1990).

[8] D.K. Todd and L.M. Mays, Groundwater Hydrology (Third Edition, John Wiley \& Son, Inc.United State of America, 2005) 